\title{
Kernos
}

Revue internationale et pluridisciplinaire de religion grecque antique

27 | 2014

Varia

\section{Julia KINDT, Rethinking Greek Religion}

\section{Paraskevi Martzavou}

\section{(2) OpenEdition}

\section{Journals}

\section{Electronic version}

URL: http://journals.openedition.org/kernos/2228

DOI: $10.4000 /$ kernos.2228

ISSN: 2034-7871

\section{Publisher}

Centre international d'étude de la religion grecque antique

\section{Printed version}

Date of publication: 1 November 2014

Number of pages: $445-448$

ISBN: 978-2-87562-055-2

ISSN: 0776-3824

\section{Electronic reference}

Paraskevi Martzavou, « Julia kINDt, Rethinking Greek Religion », Kernos [Online], 27 | 2014, Online since 12 November 2014, connection on 22 September 2020. URL : http://journals.openedition.org/kernos/ 2228 ; DOI : https://doi.org/10.4000/kernos.2228

This text was automatically generated on 22 September 2020

Kernos 


\title{
Julia KINDT, Rethinking Greek Religion
}

\author{
Paraskevi Martzavou
}

\section{REFERENCES}

Julia KINDT, Rethinking Greek Religion, Cambridge, Cambridge University Press, 2012. 1 vol. $15 \times 23 \mathrm{~cm}$, xiii+235 p. ISBN : 978-0-521-12773-8.

1 This book is a reworked version of previously published papers, with some additional material. Its main stated goal is "to explore ancient Greek religion beyond the polis" (p. 6). K. starts out by stating that scholarshipon ancient Greek religion is characterized by omissions and shortcomings, which $\mathrm{K}$. aims to address in six chapters. Some of these supposed deficiencies are listed in the introduction: the limited extent of current research on religious beliefs and religious discourse, private religion, magic and mystery religion. Each chapter presents a different aspect of ancient Greek religion and of its study and sets out to remedy what is said to be the absence or mistreatment of this theme in earlier research.

2 In the first chapter, which bears the weight of the entire volume (p. 12-35), K. criticizes the so-called model of "polis-religion"; she considers the polis as a structuring principle but sees it as too simple, especially for the study of 'personal religion' and 'mystery religions'. A second chapter (p. 36-54) analyzes visuality in Greek religion. It sets out to explore the 'cognitive dimension' of ancient Greek religion, related to the history of mentalities, as perceived and described in other disciplines. The third chapter (p. 5589) focuses on power and its symbolism in Greek religious rituals (the example is the ritual reuse of the property of the Thirty Tyrants in Athens); it examines religion as a symbolic order mapped onto the structures of Greek society. The fourth chapter (p. 90122) deals with the place of magic in the religious practices of ancient Greece. It aims to illustrate the complex relationships between magic and polis religion but it is critical concerning preconceived polarities. The fifth chapter (p. 123-154) goes through "local" and "universal" aspects of Greek religion; it aims to challenge the models of identities constructed through dedicatory and ritual activity in big sanctuaries; the sixth and 
most original chapter (p. 155-189) thinks through the construction of the divine during the Second Sophistic with the help of an approach based on the senses. It examines aspects of the corporeal representation of the divine in the religions of Greece and Rome. There is also a brief chapter of conclusions. The book is written in a lively prose and gradually constructs a number of anthropological models for the study of Greek religion.

This book surprises in more than one ways. In view of both recent and less recent scholarly work in Classics and in the history of religion, it is startling to learn that (p. 2) “... not so long ago, ancient Greek religion was regarded as a marginal topic, far removed from the surfaces of Greek life, Greek politics and society...". More than once the author states the obvious, and one wonders if this is just a question of style. K. (p. 7) writes that "...it is not just the works of Homer and Hesiod that are obvious sources for the study of Greek religion-religious; beliefs and practices can also be found in the form of curse tablets...", a statement that would not come as a surprise to generations of epigraphists, numismatists, papyrologists, at least since the end of the $19^{\text {th }}$ century. K's notion of Christianity as something immutable (p. 16 and 188) also gives pause. Finally, the use of term "Greek" throughout the book without chronological and geographical parameters is highly problematic.

4 The book is strikingly ambitious. From apparatus and bibliography, K's intention emerges, namely to urge a more systematic application of anthropology (C. Geertz, D. Gellner) in the study of Greek religion (see mainly ch. 3), a positive effort in itself, since it broadens the horizons of scholarship, and creates the space for an interdisciplinary and cross-cultural perspective. Yet (without wanting to open a whole can of worms) one might wonder if anthropology per se solves what $\mathrm{K}$. perceives as shortcomings of the "political" approaches to Greek religion (p. 80-89): anthropology comes with its own baggage, as a discipline shaped in colonial contexts and as a result of colonial encounters; anthropological approaches are themselves tainted by power relations and do not allow us to think ourselves away from power and politics. ${ }^{1}$ Anthropology might prove less useful here than a very firm sense of history and, indeed, of politics.

5 The main trope in the book is moving away from "polis-religion," but K.'s own history of the scholarship on this topic is incomplete, and the historiographical account which is meant to support a "re-thinking" of Greek religion is brief, selective and subjective. K. puts much emphasis on Jane Ellen Harrison before moving to the next stage, "polisreligion", which, is said to have found its principal mouthpiece in the person of Christiane Sourvinou-Inwood. For K., polis-religion is "... a more or less static and coherent cultural system provided by the polis and her institutions" (p.191, Conclusion). This static picture may be less a problem with the model of polis religion than with K.'s own model and understanding of the polis. K.'s scholarship of the polis is hour-glass shaped, with items from the beginning of the $20^{\text {th }}$ century and then jumping to the 80 's or 90 's - and ending there. Much of the recent continental scholarship on the polis (of extraordinary precision and dynamism) is missing. ${ }^{2}$ Methodologically, more problematic is K.'s dependency on works with an explicit focus on religion, which does not allow her to recognize the heuristic possibilities of a critical approach to the Greek polis as a formation in tension. The study of the polis and therefore of polis-religion, is much more nuanced than $\mathrm{K}$. wants to believe. The polis is a reality and also a 
discursively constructed concept: any critical assessment of the polis-religion model for the study of religion should take into account the debates about the nature of the polis.

6 Furthermore, differentiation between different historical periods is necessary, so that " polis" religion must be related to the polis of a particular period: the Archaic polis is not the Classical, nor the Classical the Hellenistic, let alone the late Hellenistic or Roman polis. ${ }^{3} \mathrm{~K}$. is of course well aware that the study of Greek religion has a history, but the history she provides is not the only possible one: the selective nature of her polis model means that the polis-religion model she presents is, largely, a straw-man, attacked with gusto, much preaching of principles and polemic, but few concrete examples or analysis of evidence. Her work is almost a manifesto. The tendency in building up and attacking straw men is unfortunately a constant feature of the work. When talking, for instance, about the symbolic value of rituals, K. writes (p. 82): “... A more dynamic approach is needed in classical scholarship that does not depict religious beliefs and practices merely as a disguise for ambitions in the political sphere..." The need has long been recognized, and it is difficult to imagine anyone, within the last generation at least, speaking of ritual as a mere disguise of political ambition. Recent work, notably on the "emotional turn", the study of the construction and display of emotions in ancient sources, has taken matters much further. ${ }^{4}$

7 While the book invites us to rethink "Greek religion",none of the chapters offers, or suggests, a chronological and geographical frame as the appropriate context for this process of "rethinking". Greek religion and its study are not only considered as topics to think "beyond the polis," since the reader practically ends up having to think beyond time and space. This is a misstep not only in the process of "re-thinking" but also in the process of merely "thinking" Greek religion. Chapter 6, which develops shrewd insights in the function of the divine as a point of reference in the exploration of love and sexuality (p.169), has the term "Second Sophistic" in its title, but would have benefitted from a sketch of the significant features of this literary and political phenomenon, or even a deeper analysis of its historical specificity.Stripping the study of Greek religion of inquiries about historical processes and changes is not a remedy to any perceived failings of the study of Greek religion. Greek religion and its aspects are subject to history and to change as much as the polis as institutional formation and representation.

8 A further example of how this lack of historical awareness can affect the comprehension of Greek religion is the "laughless Parmeniscus" story, which is analyzed in chapter 2. K. uses the story to discuss themes such as the religious gaze, the form of divinity, the tension between experience and expectation, or cognitive visuality. Now the anecdote is known from a passage in Athenaeus, Deipnosophistae, a source dating from the $3^{\text {rd }}$ cent $\mathrm{CE}$, but the original story comes from a lost History of Delos by one Semos, dating from the $3^{\text {rd }}$ cent BCE. Moreover, the protagonist Parmeniscus is perhaps to be identified with a dedicant (Parmiskos) in a Delian inventory of $156 / 5 \mathrm{BCE}$, and with a philosopher mentioned by Diogenes Laertius, a source of the $3^{\text {rd }}$ cent CE. The problems are historicity, transmission and reception: whatever we choose to do with the chronological gap between the original source and Athenaeus in the $3^{\text {rd }}$ cent CE, we cannot ignore it, because it poses the problem of where to locate our analyses of the anecdote, and to ascribe it to "Athenaeus/Semos" as K. does, only displaces the problem: are we dealing with religious mentality in the unspecified time of the anecdote, the time of the Hellenistic historian of Delos, or the third-century CE writer? 
Apart the story of the "laughless Parmeniscus" (p. 38-42), K. treats a small number of other case studies in her chapters: the procession displaying the property of the Thirty Tyrants based on a fragment of Philochorus (p. 83-89), the case of a hunting scene from the life of Apollonius of Tyana (p. 104-109), an example of agalmatophilia based on a fragment of a lost play by the poet Alexis (p. 155-156). In these case-studies, the bulk of the argumentation is based on secondary treatment of examples already constructed by other scholars and skimps on direct contact with a sufficient array of sources. The point is not just the analysis of structure and themes, but how to map these out on historical change and context. Religious history is still history, and thematic analysis, however fine, does not change this starting point.

Ideally the book is conceived [p. 8] “....as a critical evaluation of where research in Greek religion stands at present..." It is not easy to say, however, which kind of audience this book is targeting, and I am not entirely sure whether it does reveal where research in Greek religion truly stands. If this is a book conceived for beginners in the study of Greek religion - and indeed of Greek history and society - then the survey that it offers is too narrow in scope, and the examples treated are not properly contextualized historically and geographically. There is simply not enough emphasis on sources and their problems or on the historical awareness of the context and the sources treated. What is important in an introductory work is to unpack the kind and the nature of those sources we have, the challenges we face in the study of each type of source, where to be careful and of what: how we know as well as what. On the other hand, if this is a book destined to advanced scholars, then it somehow misses the target, because colleagues in the field are already familiar with the aspects of Greek religion addressed in the work. This study can be very useful to people who have an interest in Greek religion and would like to expand their bibliographical horizons towards anthropological perspectives. The critical evaluation of the research in Greek religion that this book offers, however, remains subjective and superficial since it offers no specific chronological, geographical, or historical background for the thoughts on Greek religion developed.

To "re-think" Greek religion is both a magnificent ambition and a serious challenge but the basic parameters of space and time should be introduced. It is the opinion of this reviewer that the historical approach of the Greek religion should be a sine qua non parameter, whatever the focus one choses to impose might be. We cannot think or rethink Greek religion but historically. The issue of theology that emerges at the end of the book as the ultimate question concerning Greek religion (p. 193), cannot be approached in a really satisfactory way without a serious focus on the sources. These have to be contextually and critically assessed. The interpretative turn, which the author claims as a 'sacred' principle (p.58) is and will always be historical in its very essence. 


\section{NOTES}

1. For a recent study deconstructing the uncritical use of anthropology within classics see V. AZOULAY, "Du paradigme du don à une anthropologie pragmatique de la valeur," in P. PAYEN, E. SCHEID-TISSINIER, Anthropologie de l'antiquité. Anciens objets, nouvelles approches, Brepols, 2012, p. 1742.

2. P. Gauthier and others insisted on the crucial importance of contextual understanding of the polis in its historical, and also its geographical, diversity; see for instance a sample of his transformative work recently gathered in a volume (D. ROUSSET (ed.) Philippe Gauthier, Études d'histoire et d'institutions grecques, Genève, 2011); P. FRÖHLICH, Chr. MÜLLER, Citoyenneté et participation à la basse époque hellénistique, Genève, 2005 gives a sense of the debates and their evolution. There is no mention either of the fundamental work of epigraphists such as Louis Robert, which furthered our knowledge and understanding of numerous aspects of Greek religion and of the Greek polis, in micro-historical forms combined with a sweeping sense of big historical theme; See now his Choix d'écrits ed. by D. RousseT, I. SAVALli (Paris, 2006).

3. As an example of a nuanced, contextualized study of polis religion for the Hellenistic period, see Fr. GRAF, "Bemerkungen zur bürgerlichen Religiosität im Zeitalter des Hellenismus," in M. WÖRRLE, P. ZANKER, Stadtbild und Bürgerbild im Hellenismus, Munich, 1995, p. 103-114. For the "long Hellenistic Age", see A. CHANIOTIS, "Staging and feeling the presence of God: Emotion and theatricality in the Greek East," in L. BRICAULT, C. BONNET, Panthée: religious transformations in the Roman Empire, Leiden/Boston, 2013, p. 169-189.

4. See for instance books such as W. HARRIS, Restraining Anger: the ideology of anger control in Classical Antiquity, Cambridge Ma./London, 2001. See also A. CHANIOTIS, Ritual dynamics in the Ancient Mediterranean: agency, emotion, gender, representation, Stuttgart, 2011.

\section{AUTHORS}

\section{PARASKEVI MARTZAVOU}

Corpus Christi College, Centre for the study of Greek and Roman Antiquity, Oxford 